\title{
Privatization of Social Security Retirement Systems: \\ Lessons and Comparisons from Chile, Argentina, and the United States
}

\author{
Elisa Walker
}

P

etirement pensions are traditionally provided through government social insurance systems, which pool risks broadly across the population and provide benefits that are set in law. In contrast, under privatized systems, workers' benefits depend on their own individual account balances and investment returns, with little or no redistribution and pooling of risk across the population. In 1981, Chile became the first country to fully privatize its social security retirement system, setting an example that Argentina and numerous other countries later emulated. More than two decades later, both Chile and Argentina undertook "re-reforms" to their privatized systems, with Chile maintaining its privatized system while Argentina returned to a fully public system. The United States also confronted efforts to privatize its Social Security system around the same time periods - in the early 1980s and the early 2000s-but ultimately chose to strengthen the existing system rather than privatizing.

This article examines and contrasts these three countries' experiences in the 1980s-90s and 2005-08, probing the factors that led to or prevented privatization. While finances usually provided the stated pretext for reform, privatization is now widely acknowledged to worsen the financial challenges faced by pension systems. Ultimately, neoliberal ideologies were pivotal in putting privatization on the policy agenda, and institutional structures and interest group mobilization helped to shape the outcomes of the privatization effort.

DISCLAIMER: The findings and conclusions presented in this paper are those of the author and do not necessarily represent the views of the Committee on Ways and Means or its Members. 


\section{INTRODUCTION}

In 1981, Chile became the first country to fully privatize its social security retirement system. This reform-which converted the country's social insurance program into a privatized system of individual accounts-quickly acquired a global reputation as the model of privatization. Numerous other countries emulated the Chilean model, including Argentina, which partially privatized its social security in 1994 (Turner 2005). Meanwhile, the U.S. Social Security program faced an immediate financing crisis in the early 1980s, leading to a major package of reforms in 1983-a package that pointedly highlighted and strengthened the founding principles of the public program (Ball 2010). All three countries experienced pressure from supporters of neoliberal economic platforms during the time of these reforms and two of the three had conservative governments; yet each country reacted very differently, and their social security systems took very different paths.

Fast-forwarding to the early 2000s, both Chile and Argentina undertook "re-reforms" to their privatized systems: Chile maintained its privatized system while Argentina returned to a fully public system (Mesa-Lago 2009). Around the same time in the United States, a high-profile privatization campaign failed, after being launched by the conservative administration of President George W. Bush.

This article assesses these three countries' experiences in the 1980s-90s and the 2005-08 time periods in order to better understand the factors that contributed to or prevented privatization, as well as the outcomes and lessons learned. It seeks to answer the following questions: in the 1980s-90s, why did Chile and Argentina privatize (to different degrees) while the United States deliberately did not, despite making Social Security reform a priority? In the early 2000s, why did the United States again decline to privatize, and why did Argentina reverse its privatization while Chile maintained its system? What lessons can analysts and other countries take from these experiences? To answer these questions, the article will examine each country's experience in detail and then discuss broader themes. The findings illustrate that long-term financing concerns and especially neoliberal ideologies put privatization on the agenda, and institutional structure and interest group mobilization help shape the outcomes of the privatization effort.

\section{BACKGROUND ON PRIVATIZATION}

In general, "privatization" of social security retirement systems refers to a switch from a public, defined-benefit, and pay-as-you-go system to a defined-contribution system of individual private accounts. In the former, the contributions of current workers and employers typically finance most or all of the pensions of current retirees, with contribution and benefit levels set in national law. In contrast, under privatized systems workers (and sometimes also their employers) contribute into mandatory individual accounts that will finance their own future retirement pensions. The account balances are typically invested, earning returns based on the market 
performance minus administrative fees or commissions. Contribution rates are set in law, but benefit amounts depend entirely on each individual's account balance and investment returns, whether they include gains or losses.

Because privatized systems pay pensions based on each individual's account balance, there is by definition no redistribution. In contrast, traditional public social insurance programs are built on the idea of collectively pooling risk (Kritzer 1981), producing redistribution and solidarity. Pension privatization thus means that individual workers and retirees bear more of the risks individually-such as the risk of lacking sufficient income in old age or outliving one's money-with fewer societal protections (Hacker 2005; Arza 2012b).

In each of these six cases, policymakers were actively considering social security reform, and there was a real opportunity for policy change to be enacted. Yet these three countries took very different paths in response to their reform efforts, which resulted in very different outcomes and levels of risk for workers in each country.

\section{CHILE: 1981 AND 2008}

\section{REFORM}

By the late 1970s and early 1980s, Chile's retirement pension program was under stress in many ways. Financial pressures were the most alarming issue: the program provided relatively low benefits to retirees but at relatively high cost, and increasing government subsidies were required to keep the system operational (Rix 1995). The system was comprised of a multitude of different programs and funds, segregated by occupation, each with different rules and benefit levels (Kritzer 1981). Other problems included inflation, inefficiencies, widespread payroll tax evasion, and low rates of coverage among workers (Kritzer 1981). Only 70 percent of the population was covered despite the existence of "more than 160 different funds regulated by more than 2,000 laws" (Borzutzky 2005, 657). In short, the Chilean system was "expensive, chaotic, stratified, and unequal" (Borzutzky 2005, 657). The Chilean public was aware of these challenges; "most Chileans agreed that the old social security system required significant changes," though not necessarily total replacement (Kritzer 1981, 36). However, in late 1980, the U.S.-backed military dictatorship under Augusto Pinochet decreed a radical change to the pension program to take effect the following year: privatization.

Under the new system, each worker would contribute a mandatory 10 percent of earnings into their individual account, with the accounts managed and invested by new pension management companies, or AFPs (Administradoras de Fondos de Pensiones) (Rix 1995). Employer contributions were eliminated, ostensibly to increase employment (Kritzer 1981; Rix 1995). Each worker's personal account contributions and balance determined the pension amount they would receive upon retirement. New workers entering the labor force in 1981 and later were automatically entered into the new privatized system. Current workers could choose to stay in the old system or switch to the new private system, with the government funding a "recognition bond" 


\section{Featured Articles}

representing the accrued value of their past contributions (Borzutzky 2005). By the end of 1982, nearly 70 percent of the current workers had chosen to move to the new system, thanks to severe cuts in the existing benefits and also a large publicity campaign emphasizing the flaws of the old system (Mesa-Lago 1994).

The military and the police were notably exempt from the reform and their existing, relatively generous systems were preserved (Arenas de Mesa \& Bertranou 1997). Not surprisingly, a military regime exempting the military from an unpopular reform created "resent[ment]" of the particular advantage allowed for this "very privileged group" (Hiltzik 2005, 181-183); it also "undermine[d] some of the principles of these reforms, such as standardization of entitlement conditions and elimination of privileges" (Arenas de Mesa and Bertranou 1997, 28). However, it clearly reflected the power structure of the regime.

The rationale given for the privatization reform focused on the unsustainable financing and other challenges of the existing system. The reform's goals were described as "to reduce public sector social insurance costs and eliminate the inequities endemic to the old system" (Rix 1995, 1-2) and "to switch the burden of retirement to the individual, lessen the government's financial responsibilities, stimulate the economy, and encourage employment" (Kritzer 1996, 46). Each of those reflected a particular challenge of the pre-reform system.

While those challenges provided the pretext, they arguably were not the main cause of the reform. A 1979 law had addressed many of those problems already, including by reducing costs and eliminating some of the most egregiously expensive and unequal pensions (Borzutzky 2005). At a more fundamental level, the pension privatization was driven mainly by the deeply held neoliberal ideology that was central to the Pinochet regime (Piñera 2010; Borzutzky 2005). The "Chicago Boys" economiststrained in the United States and promoting a neoliberal school of thought focused on the free market, individual freedoms, and markets over state intervention-had become increasingly influential in Chile since the 1950s, and the Pinochet regime put them squarely in control of the country's economic policies. They believed above all that "the market is the only social arrangement capable of regulating human interaction without coercion, simultaneously guaranteeing freedom and rationally based behavior. The goal was to have the market replace the state as the central regulator of economic activity, guaranteeing efficiency and growth" (Borzutzky 2005,659 ). Shifting to a system of private accounts fit with this notion of individual responsibility and reduced government protections.

The new privatized system quickly encountered challenges. It had low rates of coverage and low rates of contributions even for those who were enrolled in private accounts-which was worrying given that future pension amounts were directly tied to the account balance. By the mid-1990s, only about 55 percent of the labor force was actively contributing to an individual account (Kritzer 1996). The transition costs of switching from a pay-as-you-go system to an advance-funded system were also extremely high; the Chilean government funded this using the large government 
surplus (Hiltzik 2005), which itself had been accumulated partly through other privatization reforms, namely "the sale of state-owned enterprises to the private sector" (Kritzer 1996, 46; Diamond and Valdés-Prieto 1994). The AFPs also charged high and often regressive administrative fees and commissions: several studies estimate that the administrative costs, compounded over time, amounted to onequarter to one-third of the accounts' savings (Turner 2005; Diamond 1993). Still, the strength of the Chilean stock market at the time enabled the privatized system as a whole to perform reasonably well in the short term, at least for those who were regularly contributing (Hiltzik 2005; Hiltzik 2016). Over the longer term, however, its many challenges became more apparent, especially once workers began retiring on their often-inadequate individual pensions.

\section{RE-REFORM}

Chile's 2008 "re-reform" of its privatized pension system after 27 years is notable for maintaining-and in some ways improving - the system of individual accounts and for doing so in a process that deliberately included broad social dialogue (Mesa-Lago 2009). In 2006, the president convened an advisory council, known as the Marcel Commission after its chairman Mario Marcel, to evaluate the pension system and make recommendations (Kritzer 2008). It had representation from multiple sectors and held numerous public meetings (Mesa-Lago 2009, 605). Its report comprehensively examined the system-including challenges such as coverage and contribution rates, pension (in)adequacy, gender inequities, high fees and low competition among AFPs, and other issues-and issued recommendations for improving the privatized system (Kritzer 2008).

The resulting law, enacted in 2008, was "based largely on" the findings of the report (Kritzer 2008), and made reforms aimed at addressing many of those issues: it eliminated monthly fixed fees, added a basic universal pension for those not eligible for any other pension, added a "maternity voucher" to increase gender equity, and created new rules to encourage voluntary retirement savings, among other changes (Kritzer 2008; Mesa-Lago 2009). Prominent Latin American welfare scholar Carmelo MesaLago applauded the Chilean re-reform for being "preceded by social dialogue" and concluded that it "is comprehensive and promotes the majority of [the International Labour Organization's] social security principles" $(2009,612)$.

However, the system's ultimate results-especially once enough time passed that workers started retiring based only on contributions into the privatized system-have been far worse than that positive appraisal might imply. After mostly positive results in the short term (thanks to "an unprecedented bull market in Chilean stocks"), the longer-term returns and thus pension amounts have fallen far short of expectations: high AFP fees, low returns to workers, and as a result, very low pension amounts (Hiltzik 2005, 182-183). Chile's average pension is only $\$ 315$ a month, and there is a very large gap between average investment returns ( 8 percent) and the average returns to workers after administrative fees (3 percent) (Fultz 2017). Pinochet's "promise was that pensions would provide 70 [percent] of a worker's final wages at work; the 


\section{Featured Articles}

real figure is 38 [percent], the lowest rate among developed countries other than Mexico" (Hiltzik 2016). Moreover, there are very low coverage and contribution rates among some groups-only "about 30 percent of low-income workers contribute[d]" to individual accounts in 2006-indicating that future retirees may receive even lower benefits (Kritzer 2008, 74). Most strikingly, the nature of a system based on individual accounts with no redistribution or progressive structure means that it exacerbates, rather than relieves, the inequalities produced in the market economy (Borzutzky 2005). On the whole, outcomes from the privatized system do not appear to be positive for most workers and retirees.

\section{ARGENTINA: 1994 AND 2008}

\section{REFORM}

Argentina's pre-reform public pension system experienced many of the same issues as Chile's system, including financial pressures in the form of "growing deficits" requiring government subsidies, "high payroll taxes that promote[d] under-reporting of income and [tax] evasion," uneven benefit levels, and "lax entitlement conditions" (Arenas de Mesa \& Bertranou 1997, 4). In 1993, the government enacted a comprehensive reform that took effect in 1994. The Argentine reform is considered a partial privatization or mixed system, as the public system was made optional, rather than being abolished (Turner 2005; Kritzer 2002). The new "integrated" system consisted of three tiers: a flat-rate universal benefit (based on years of contributions) for the lower-income only; an earnings-based benefit for contributions before 1994; and an individual choice between the public program and a private individual account (Kritzer 2002). Much like in Chile, investment management companies called AFJPs (Administradoras de Fondos de Jubilaciones y Pensiones) managed the individual accounts and charged fees and commissions for that service (Arenas de Mesa \& Bertranou 1997).

However, the mixed system had some key differences from Chile's fully privatized system. Arenas de Mesa and Bertranou (1997) argue that the variations arose at least partly as a result of Argentina learning from Chile's experience and improving upon the design of the plan. Argentina's system was publicly administered (central collection of payroll taxes), which is far more administratively efficient than Chile's method of having each AFP run its own collection (Arenas de Mesa \& Bertranou 1997). Argentina also had a publicly managed AFJP, which provided "a minimum rate of return for the pension fund equivalent to the interest rate for deposits in its savings accounts" (Arenas de Mesa \& Bertranou 1997, 24). Compared to Chile, Argentina had lower transition costs, higher coverage, more solidarity (redistribution), less gender inequity, and better regulation of the pension funds (Arenas de Mesa \& Bertranou 1997).

The system still faced many challenges, including low coverage rates-with only 54 percent of the employed labor force contributing to the system-and benefit levels that were likely to be relatively low for women and low-income workers (Arenas de Mesa \& Bertranou 1997). For instance, women's benefits in the mixed system were projected to be 10.5 percent lower than men's, because women typically live longer 
and thus must fund more years of pensions from their individual accounts (Isuani et al. 1996, cited in Arenas de Mesa \& Bertranou 1997). High fees were also a problem, despite somewhat more regulation than in Chile: by 2007, fees averaged nearly 18 percent of the mandatory contributions (Kritzer 2008). In addition, by "depriv[ing] the government of a large amount of tax revenue," the privatization reform contributed significantly to Argentina's government deficits and economic crisis in the early 2000 s (Baker \& Weisbrot 2002).

\section{RE-REFORM}

Among the Latin American countries that undertook a second round of pension reforms in the early 2000s, Argentina was an exception: rather than amending and improving its partially privatized system, it "re-nationalized" the system - that is, it ended the privatized system and absorbed the funds and the workers back into the public system (Bertranou, Calvo, \& Bertranou 2009). This was partly prompted by the numerous problems with the mixed system discussed above, including high fees and low coverage rates. Many retirees did not meet the work history requirements to receive a minimum pension, regardless of their poverty levels (Mesa-Lago 2009). In addition, Argentina's 2001 economic crisis had "provoked a drastic fall in coverage and the value of the pension fund" (Mesa-Lago 2009, 604), and benefits in the public system were cut by 13 percent (Arza 2012b). The government appointed an expert commission on possible reforms and sponsored an assessment by the International Labour Organization in response to the crisis, but did not make any changes (Arza 2012a).

Under the reform passed in 2008, the government took over the funds in the individual accounts, and also assumed responsibility for all future pension payments. Workers with individual accounts were "guaranteed" that their public pensions would be as good or better than what they would have received, but that guarantee was essentially meaningless given the nature of a privatized system, where benefits depend on future investment returns (Angelaki \& Carrera 2015). As discussed more later in the paper, Argentina's enormous macroeconomic pressures were central to motivating this reform, because taking over the accumulated pension funds helped the government be able to meet its required international debt payments.

Data on Argentina's outcomes are not readily available; however, the Organisation for Economic Cooperation and Development (OECD) indicates that replacement rates (the percentage of prior income replaced by the typical pension) are above OECD averages (OECD 2017, Table 4.2, 101). For example, average replacement rates for men with mean earnings are 72 percent in Argentina compared to 53 percent in the OECD as a whole; for women, it is 64 percent compared to 52 percent.

\section{UNITED STATES: 1983 AND 2005}

\section{REFORM}

The major Social Security reform in the United States in 1983 deliberately maintained the traditional social insurance structure of the pension program. The reform process 


\section{Featured Articles}

started in late 1981, when President Ronald Reagan appointed a bipartisan commission, known as the Greenspan Commission after its chairman Alan Greenspan, and charged it with recommending changes to Social Security (Ball 2010; Hiltzik 2005). The commission members represented a wide range of interests, ranging from elected officials to public representatives of business and labor organizations (Altman and Kingson 2015). The commission's final report started with a ringing reaffirmation of Social Security's existing principles, stating that changes "should not alter the fundamental structure of the Social Security program" and that they had "considered, but rejected" changes such as privatization (National Commission on Social Security Reform 1983).

The commission report became the basis of the 1983 reforms passed by Congress, which included increasing the retirement age, making some benefits taxable, extending coverage to newly hired federal employees, and delaying cost-of-living adjustments. On the whole, its short-term adjustments were "a reasonably balanced mix of contribution increases and reductions in benefits" (Gregory et al. 2010, 5); however, its long-term plan was mainly benefit reductions, which will "ultimately lower Social Security benefits for retirees by an average of 19 percent" (Reno, Bethell, \& Walker 2011). The retirement age increase-effectively a benefit cut-was implemented so gradually and so far out in the future that its full effects still remain to be seen.

\section{REFORM ATTEMPT}

In 2005, the United States again rejected privatization, this time despite a conservative president actively advocating for it. President George W. Bush had spoken prominently about Social Security privatization during his 2004 presidential campaign and again in his State of the Union address in early 2005 . He then rolled out a proposal (based on a 2001 Social Security commission to which he had appointed almost entirely privatization supporters) and embarked on a nationwide tour and publicity campaign to sell it (Hiltzik 2005; Galston 2007). The plan had clear echoes of the Chilean privatization model, down to the use of "recognition bonds" for workers transitioning from the public to the private system (Hiltzik 2005; Hiltzik 2016). As Bush toured the country touting his privatization proposal, he met with a groundswell of public opposition. It quickly became clear that while the public liked the general ideas of ownership and freedom, they were not in favor of private accounts if it meant reductions in Social Security's guaranteed benefits, as Bush was proposing. His proposal "would have cut benefits for the upper 70 percent of future retirees," starting at people earning $\$ 25,000$ a year (Galston 2007, 5). As a result of the widespread public outcry, Democrats and many Republicans in Congress publicly opposed the plan, and even the Bush administration had to concede defeat within 10 months.

Turning briefly to outcomes, the U.S. Social Security system provides average retirement benefits of approximately $\$ 1,400$ a month, with a progressive benefit formula that provides relatively larger benefits to lower earners (Social Security Administration [SSA] 2018). While many criticize the system for providing inadequate benefitsand indeed, most developed countries have far more generous retirement pensions 
(OECD 2017) - it is widely recognized as "the most effective anti-poverty program" in the country and has dramatically reduced elderly poverty rates (Gould 2013).

\section{DISCUSSION}

Comparing these three countries' experiences with reform yields useful lessons on factors that contribute to causing_or preventing-privatization reforms. Of the six cases of potential policy change, four were what can be considered privatization efforts, where the government was actively pushing privatization or where there was a real possibility of a policy change in that direction. Some of those privatization efforts were successful (Chile in 1981 and Argentina in 1994) and some were not (the United States in 1983 and 2005). When Chile and Argentina embarked on "rereforms" in 2008, the systems were already privatized, so the situation was rather different; still, those cases provide important insights to the analysis.

Concerns about long-term social security financing are used as justification for nearly all reforms of these systems, but this does not explain why privatization in particular is on the agenda as a solution-especially given that it exacerbates these financing challenges. Instead, political and economic ideologies are fundamental in shaping the direction of the proposed reforms, with neoliberalism motivating all the privatization efforts discussed here. Once privatization is on the policy agenda, institutional structure and interest group mobilization are particularly important in shaping the outcome of the reform effort. Having an institutional structure that limits the opportunities for input or vetoes, and little to no effective interest group mobilization, makes it possible for privatization reforms to succeed. In contrast, the combination in the United States of high and ongoing interest mobilization around Social Security, and a decentralized government with many opportunities for public influence, presents especially high barriers to privatization. Beyond those primary factors, additional conditions such as an immediate social security financing crisis, macroeconomic pressures, and the role of experts and commissions can sometimes influence reforms in certain situations.

\section{LONG-TERM FINANCING CONCERNS}

In each of the four privatization efforts, concerns about the long-term financial sustainability of increasing pension costs appeared to play a significant role in prompting reforms. For instance, Chile's pre-reform system required ongoing government subsidies that were expected to increase "nearly tenfold in 20 years," and these increasing subsidies were frequently discussed as a cause of the reform (Kritzer 1981, 34). However, a deeper analysis shows that while financial pressures nearly always provide the pretext for privatization efforts, privatization in fact exacerbates financial pressures. Diamond expressed surprise about "the high cost of running a privatized social security system" in Chile $(1993,1)$, and went on to conclude that "[r]ather than privatization being a cure for a chronic deficit, it may be the case that a surplus is an important condition for a successful privatization" (1993, 16-17). 


\section{Featured Articles}

Indeed, "the cost of [Chile's] pension system for the state was twice as high in 1999 as it was in 1980" (Borzutzky 2005, 669). Argentina also struggled with high costs of its partially privatized system, compounded by the country's broader deficits: "[in] fact, the deficit created by Social Security privatization is almost exactly equal to the government budget deficits that Argentina ran in [1994-2001]" (Baker \& Weisbrot 2002). The U.S. Greenspan Commission in 1983 showed some awareness of the fact that privatization would exacerbate Social Security's financial challenges, and that helped contribute to steering the discussion away from privatization.

Thus, we should be wary of arguments that financial pressures are the driving force toward social security privatization. While long-term finances usually provide the stated pretext for reforms, privatization is now widely acknowledged to worsen financial challenges.

\section{NEOLIBERAL IDEOLOGY}

Neoliberal pressures were a key inspiration behind each of the privatization efforts studied here. Both in Chile under Pinochet and in Argentina under President Carlos Menem, the social security privatization reforms were seen as the central piece of the government's broader neoliberal economic strategies. The Chicago Boys band of neoliberal economists consolidated power under Pinochet and undertook a series of market-based reforms, including pushing through social security privatization with the support of the dictator (Borzutzky 2005; Piñera 2010). The regime's goals for that reform included reducing the state's role in pensions, which fit with the ideological underpinnings of the reform (Mesa-Lago 1994). Likewise, Argentina's partial privatization formed part of a broad-scale privatization campaign that Menem was undertaking across many different sectors, involving the sale of state-run enterprises in railroads, utilities, TV stations, airlines, oil companies, and more. This privatization campaign in turn was linked to an even broader process of "economic liberalization" including reducing both regulations and workers' bargaining power (Calvert 1996). Borzutzky (2005) and Arza (2012a, 48, citing Cortés and Marshall 1999), respectively, argue that these neoliberal movements were a driving force behind the privatization reform in each country.

Privatization attempts in the United States were also motivated heavily by ideology, especially leading up to 2005 (Hiltzik 2005). Groups pushing for privatization that year, such as the conservative Cato Institute, did not hide the fact that they "saw the issue in terms of ideology, not economics - as a classic battle to promote libertarian ideals" (Hiltzik 2005, 212). For example, a Cato analyst acknowledged, "In the end, this isn't a debate about the system's solvency [...] it's about whether you think the government should be in control of your retirement or people should take ownership and responsibility" (quoted in Hiltzik 2005, 212). Similarly, a 2005 internal White House memo described the privatization effort as "one of the most important conservative undertakings of modern times" (Altman 2018). In 1983, too, President Reagan and his budget director were "philosophically opposed to all big government programs other than military" (Ball 2010, 2), and appointed the Greenspan Commission only after 
trying — and failing—to drastically cut Social Security benefits in 1981 (Ball 2010). The commission itself also heard directly from one "early proponent of privatization" (Ball 2010,27). In short, privatization efforts in all three countries were motivated in large part by neoliberal ideologies.

Argentina's experience in the 2008 re-reform also demonstrates the importance of ideology, albeit an ideology of a different type. By increasing the government's role as "the main provider of retirement income," the pension renationalization "fitted with the overall orientation of the government macroeconomic policies of more state intervention in the economy" (Angelaki \& Carrera 2015, 16). President Cristina Fernández de Kirchner had nationalized several other enterprises during her tenure, including some that had been privatized under Menem in the 1990s (Romero \& Minder 2012).

Industry profits can also be closely related to ideology, as political elites are often linked to financial elites. For instance, Chile's largest two AFPs, which controlled 60 percent of the market, had direct ties to the Pinochet regime's neoliberal economists (Dahse 1979, cited in Borzutzky 2005). The financial industry typically stands to gain a massive influx of investments under a privatized system where private investment companies manage the individual accounts and set commissions or fees. Not surprisingly, then, the financial industries in both Chile and Argentina reaped large profits post-privatization, with "the industry profit margin exceed[ing] 50 percent [...] in some years" in Chile (Hiltzik 2005, 183). Similarly, in the United States, a privatization reform in 2005 would have handed "the investment and insurance industries [...] an unprecedented amount of revenue" (Hiltzik 2005, 16). Research conducted by economist Austan Goolsbee indicated that this would have represented "the largest windfall for financial managers in American financial history" (as quoted in Hiltzik 2005,17). This profit motive both feeds on and contributes to the ideological pressures toward privatization.

Political and economic ideologies clearly played an important role in these pension reform efforts, with neoliberal pressures especially likely to put privatization on the policy agenda.

\section{INSTITUTIONAL STRUCTURE AND INTEREST GROUP MOBILIZATION}

Once privatization is on the agenda for reform, two closely related factors appear particularly important in shaping its outcome: the government's institutional structure (including the degree of centralization, veto points, and opportunities for public input), and the degree of effective interest group mobilization. Privatization tends to generate strong opposition because it is typically accompanied by large reductions in the guaranteed (that is, public) pensions. However, the degree to which public sentiment shapes policy outcomes depends not only on interest group mobilization, but also on the institutional structure of the government. In general, countries with low interest group mobilization and/or highly centralized governments-where the executive holds a strong degree of policymaking authority, where there are few 


\section{Featured Articles}

other "veto points" in the policymaking process, and where opportunities for public influence are limited-appear to have a higher likelihood of privatizing. In contrast, when the institutional structure allows many opportunities for input or vetoes and interest groups are highly mobilized, there are likely to be strong barriers to privatization.

Chile's privatization under a military dictatorship presents an extreme case; as one might expect under those circumstances, the reform was announced and implemented unilaterally, with no legislative process and little to no public input (Kritzer 1981; Mesa-Lago 1994). As Kritzer explained, "[i]t is important to note that these reforms were proclaimed by executive decree and not by a plebiscite. Labor unions were not consulted" $(1981,36)$. Kay $(1999,409)$ emphasizes that the reform "generated opposition from a range of interest groups [...]. However, the repressive dictatorship largely ignored these groups." This is not to imply that there was no discussion of the reform; however the political debates were "transferred from the public sphere to the intragovernmental spheres. It was within the regime, and specifically within the junta, that the discussions about the extent of the reform took place" (Borzutzky $2005,670)$. As the proponents of a more corporatist welfare state ideology-who had argued for changes within the existing pension system-fell out of favor during the ascendancy of the neoliberals, the possibilities of major privatization rose (Borzutzky 2005). The institutional structure of the government meant that public opposition from interest and advocacy groups, which had been strong enough to block proposed reforms as recently as the mid-1970s (Borzutzky 2005), had no opportunity to affect the direction of the privatization reform (Mesa-Lago 1994). Although its origins in a dictatorship initially weakened the new system's legitimacy, especially internationally, those concerns were reduced when Chile's new democratic government in 1990 "endorsed" the privatized system (Mesa-Lago 1994, 89).

Argentina was one of the first countries with a substantial pension program to privatize under a democracy (Kay 1999), and the resulting uniquely mixed (public/ private) system stems partly from its fragmented public opposition and centralized government structure. Compared to attempted pension reforms in some other Latin American democracies, Argentina's institutional structure "provided fewer opportunities for opponents [of privatization] to act as veto players" (Kay 1999, 417). Specifically, President Menem frequently used emergency executive decrees to bypass the normal legislative process, weakening the legislature's power. Argentine legislators were also heavily dependent on the central political parties, and thus less likely to bow to interest group opposition.

In addition to the institutional structure limiting opportunities for input, Argentina's interest groups did not effectively mobilize against privatization. The labor and other opposition movements were very fragmented due to political divides and "failed to form a durable coalition" against the reforms, while business and pro-privatization groups were more effective (Kay 1999, 411-412). Though there was some opposition from the public (a massive anti-privatization petition in 1993 had amassed 1.3 million signatures in just three months), many others were unaware of privatization's effects 
(Kay 1999). Ultimately, even the limited amount of stakeholder involvement "was one of the most important factors explaining why the Argentinean public pay-as-you-go system was reformed and not completely substituted, as in Chile" (Arenas de Mesa \& Bertranou 1997, 32). Despite not mobilizing effectively enough and not having enough opportunities in the institutional structure to fully defeat the privatization reform, opposition groups did influence it enough to hold it to a partial, rather than full, privatization.

In contrast, the combination in the United States of a decentralized government with many veto points, and high and ongoing interest mobilization around Social Security, presented especially high barriers to privatization. The U.S. government-with its separation of powers, limited executive role, and election structures-is considered highly decentralized, even for a democracy (Janda 2006). In 1983, for instance, the key negotiations on Social Security reform occurred between representatives for President Reagan and House Speaker Tip O'Neill, because of their positions as possible veto points for the legislation (Ball 2010,). Both were acutely aware of the need for a prominent Social Security solution. Moreover, the U.S. direct election structure meant that members of Congress (in addition to the president) were especially aware of the dangers of antagonizing their senior citizen constituents ahead of the elections. Similarly, in 2005, legislators and ultimately the president had to concede defeat on privatization after seeing the overwhelming opposition from their voters.

The role of public opinion and interest group involvement on Social Security in the United States is hard to overstate. Social Security is often called "the third rail" of American politics because politicians have long understood the danger of proposing unpopular changes. Andrea Louise Campbell (2003) argues that Social Security itself helped produce this extremely motivated, informed, and active senior citizens lobbybecause Social Security increases nearly all seniors' financial resources, allows them to retire and thus have free time for civic participation, and directly ties their interests to the government's actions.

By the time of the Greenspan Commission and the resulting 1983 reforms, Congress and the President were acutely aware of the dangers of provoking this sleeping giant of public opinion. In 1981, a widespread public outcry led by seniors' organizations had very quickly defeated a Reagan administration proposal for massive benefit cuts. It had been "the first call for cuts in Social Security benefits since the program's enactment in 1935, and it was met by a firestorm of protest" (Campbell 2003, 104). Seniors and senior organizations sprang into action and "dramatically increased" their letters and calls to Congress (Campbell 2003, 108). In just over a week, the proposal was dead (Hiltzik 2005). Senior involvement continued at a high level through the 1983 reforms, and politicians were clearly aware of that (Campbell 2003). The Greenspan Commission - which itself included a broad range of stakeholder viewsalso made a point to reach out to influential outside organizations such as AARP (Ball 2010, 28), and ultimately, the commission's proposal "was widely accepted, even by senior citizen groups" (Campbell 2003, 104). Thus, it appears that in 1983 the threat 


\section{Featured Articles}

of a widespread outcry by the very active senior interest groups helped prevent even a serious consideration of privatization or other forms of undermining Social Security.

Similarly, by all accounts, public and stakeholder opposition was the deciding factor in bringing Bush's 2005 privatization proposal to a decisive defeat (Altman \& Kingson 2015; Altman 2005; Galston 2007; Hiltzik 2005). Individual citizens and organized groups such as AARP were vehemently opposed to privatization, and they made their voices heard loudly through grass-roots protests, public forums with members of Congress, public opinion surveys, and media coverage (Hiltzik 2005; Altman 2005). Throughout Bush's nationwide tour, "support for [the plan] fell the longer he was on the road" (Altman 2005, 291). Despite some conservative interest groups (who supported privatization based on ideology) lobbying a conservative White House, this public opposition was strong enough and so effectively mobilized that it left no real chance of privatization being enacted.

Thus, the outcomes of these privatization attempts in 1983 and 2005 demonstrate that the combination of strong interest group mobilization and the context of a very decentralized government presents especially high barriers to Social Security privatization. Unlike the pre-reform systems in Chile and Argentina, the existing Social Security system is widely seen as a foundational-and successful-program for the country. It represents the legacy of the New Deal and the country's sense of solidarity, to such an extent that it prompts political participation by seniors and others far beyond what would be expected otherwise (Campbell 2003). Against that backdrop, even a concerted campaign by a newly reelected conservative president with considerable political capital was not able to overcome the opposition to privatization (Galston 2007).

Argentina's 2008 reform demonstrates similar lessons under different circumstances, as the renationalization took place under declining public support for individual accounts and a fairly centralized government pushing for the reforms. A series of incremental reforms from 2005 to 2007 had slowly increased the state's role in pensions, such as by making the public part of the system (instead of private accounts) the default option if workers "did not make an active choice," and increasing the benefits under the public part (Angelaki \& Carrera 2015, 11). By 2008, there was "a far-reaching political consensus that the private pension system established in $1993 / 94$ needed to be reformed, and that the reform should be geared toward greater state involvement and regulation" (Arza 2012a, 49). The government of President Fernández de Kirchner was heavily pushing the reform for its macroeconomic benefits (discussed below), and the centralized institutional structure meant that the Congress had a "rather limited" role; it passed the President's reform bill in just three weeks without any "substantive debate" (Arza 2012a, 49). Moreover, there was little effective mobilization of any opposition to the re-nationalization. Public support for privatized pensions was quite low-surveys showed 90 percent of Argentines said pensions should be mainly government-run (Arza 2012a) -in large part due to the unpopularity of the existing system, which was expensive, had low contribution 
rates, and had not done well in investments (Angelaki \& Carrera 2015). Just that year, the global financial crisis had caused the total private account balance to fall by one-quarter (Mesa-Lago 2009). The domestic and international financial industries opposed the reform, but their opposition was too weak to be effective (Arza 2012a).

Chile in 2008 was similar in some regards, as it also had a fairly centralized democratic government and had experienced many of the same challenges in its privatized system. However, Siavelis argues that the extremely centralized nature of the political system-with little public influence on decisions or political parties-meant that "elites avoided destabilizing change" and thus were reluctant to "engag[e] in any reform of any of the fundamentals of the economic system inherited from Pinochet" $(2016,79-80)$. Thus, the reform proposals under discussion hewed closely to the existing system, and the question of whether or not to remain under a privatized system was not even part of the debate. The Marcel Commission's recommendations focused on improving the existing system, and the government largely followed their recommendations for the reform (Kritzer 2008). As a result, there was little question of public opposition because the specific recommendations were mainly improvements to the existing system, and there was no fundamental reform under consideration.

Clearly, institutional structure and interest group mobilization are key factors in shaping the outcome of social security reform efforts, after long-term financial concerns and especially neoliberal ideologies put privatization on the policy agenda in the first place. A decentralized structure and effective interest group opposition can prevent privatization, while the opposite (a more centralized structure with limited opportunities for public influence, and a weaker mobilization of the opposition) allows it to go through. Similarly, when the question concerns a government proposal to renationalize an already privatized system, the lack of effective opposition to that reform is crucial in allowing it to be enacted.

However, additional factors can also influence reforms in certain less-common situations. The following sections explore three such factors: an immediate social security financing crisis, macroeconomic pressures, and the role of experts and commissions.

\section{IMMEDIATE SOCIAL SECURITY FINANCING CRISIS}

In contrast to the longer-term financial concerns discussed earlier, an immediate social security financing crisis may effectively prevent privatization, due to the high transition costs of switching from a pay-as-you-go system to an advance-funded system. Doing so requires essentially paying twice for a period following the reforms: the traditional public system requires ongoing payments in order to pay retirees' benefits, and yet current workers are in theory switching their contributions to individual accounts rather than continuing to contribute to the old system. Returning to Diamond's $(1993,16-17)$ conclusion that " $r$ ] ather than privatization being a cure for a chronic deficit, it may be the case that a surplus is an important condition for a successful privatization," we can take that a step further and argue that rather than 


\section{Featured Articles}

privatization being a cure for an immediate social security crisis, the presence of such a crisis may effectively rule out privatization.

The U.S. experience in 1983 clearly demonstrates the importance of this factor. By the early 1980s, it was clear that Social Security "faced an immediate funding crisis for the first and only time in its history," thanks to the turbulent economy and raging inflation of the 1970s (Gregory, Bethell, Reno, \& Veghte 2010,1). Unlike in Chile or Argentina, where the concern was a general escalation of costs, this crisis was abrupt and urgent: without immediate changes, Social Security would have been unable to pay benefits in mid-1983. The Greenspan Commission "recognized that siphoning off funds" toward private accounts would "exacerbate" this financial crisis, which helped prevent privatization from being seriously considered (Bethell 2005).

\section{THE ROLE OF EXPERTS AND COMMISSIONS}

Several countries' experiences demonstrate that these reforms differed widely in their use of advisors and experts. First, the type of experts consulted-especially whether they are primarily social security experts or general economic expertscan be important in shaping the policy outcomes (Weyland 2008). For instance, the 1983 U.S. reform was dominated by long-time Social Security policy experts steeped in, and fully convinced of preserving, the existing system's structure. Robert M. Ball, the commission's leader from the Democratic side, was a prime example: he was the longest-serving leader of the SSA, a revered leader in the field, and a staunch advocate of the existing system (Ball 2010; Bethell 2005). Ball specifically aimed "to avoid letting the commission become a forum for proposals to radically alter Social Security's fundamental principles or weaken its ability to meet the nation's present and future needs," and his influence was such that he succeeded in doing so (Ball $2010,15)$. He wrote later that the commission's affirmation of the present system was "what I still consider to be one of the most important objectives-if not the most important—that I was able to achieve in our negotiations" (Ball 2010, 58).

In contrast, Chile's 1983 reform discussions were almost completely dominated by neoliberal economists, and Argentina's two reforms apparently did not include much consultation with experts at all. In 1994, one primary inspiration was Chile, whose privatization had had an enormous influence around the world on similar reforms, especially in Latin America. Several common mental shortcuts of bounded rationality played a key role in this influence, especially the availability heuristic (with Chile's recent reform "capturing the attention" of policymakers) and the representativeness heuristic (assuming that Chile's "initially stellar rates of return" were representative of privatized systems as a rule) (Weyland 2008,186). Weyland argues that "longstanding specialists" in social security systems would have been "less easily swayed by" these mental shortcuts $(2008,194)$. Argentina's 2008 reform also included very little consultation with experts at all, due to the dominance of macroeconomic pressures in prompting the reform and "the need to resort to a quick fix" of those financial problems (Angelaki \& Carrera 2015, 6-7). 
Moreover, a variety of outcomes are possible following high-profile social security commissions and other public discussions. When commissions are fairly appointed and include representatives from a wide range of stakeholder groups-as in the U.S. Greenspan Commission (1983) and the Chilean Marcel Commission (2006)—they can help to build legitimacy for the resulting reform proposals. However, a commission that is widely perceived as being "stacked" to one side of the debate - such as the 2001 U.S. President's Commission to Strengthen Social Security, in which the White House "controlled the agenda" and vetted members in advance "to make sure that they all supported privatization" - will lack "credibility" and does not function to add legitimacy or stakeholder support (Hiltzik 2005, 189-190). Similarly, if a commission's proposals or findings are mostly ignored in the subsequent reform proposal-as in Argentina in 2008-that weakens the perceived legitimacy of the reform (Mesa-Lago 2009).

\section{CONCLUSION}

The six cases of potential social security policy change considered here represent stark contrasts in the directions their social security systems took, and they offer important lessons for other countries considering various types of reforms. Longterm financing concerns are common in social security systems, so while they are often cited as justification for reforms, they do not explain privatization in particular. However, the combination of those concerns with neoliberal ideologies tends to put privatization on the policy agenda in the first place. Next, the institutional structure and interest group mobilization can heavily influence the outcomes: effective interest group opposition and a decentralized structure that allows the public some influence can prevent privatization, while the opposite (a fairly centralized structure with limited opportunities for influence and a weaker mobilization of the opposition) allows it to pass.

Finally, and perhaps most importantly, the systems differ in how well they protect retirees against the risks of inadequate income, outliving one's resources, and poor investment returns. By moving from social insurance to a system of individual accounts, privatization shifts risks to individuals and leaves them largely unprotected from any possible shocks in old age.

\section{REFERENCES}

Altman, Nancy J. 2005. The Battle for Social Security: From FDR's Gamble to Bush's Gamble. Hoboken, NJ: John Wiley \& Sons, Inc.

---. 2018. The Future of Social Security, Medicare, and Medicaid Is on the Ballot this November. Washington, DC: Social Security Works. https://socialsecurity.news/the-future-of-social-security-medicare-andmedicaid-is-on-the-ballot-this-november/.

Altman, Nancy J., and Eric R. Kingson. 2015. Social Security Works! Why Social Security Isn't Going Broke and How Expanding It Will Help Us All. New York, NY: The New Press. 


\section{Featured Articles}

Angelaki, Marina and Leandro N. Carrera. 2015. "Radical Pension Reforms after the Crisis: a Comparative Analysis of Argentina and Greece." Politics and Policy 43 (3): 378-400. http://eprints.lse. ac.uk/62749/.

Arenas De Mesa, Alberto, and Fabio Bertranou. 1997. "Learning from Social Security Reforms: Two Different Cases, Chile and Argentina." World Development 25: 329-348. https://www.researchgate.net/ publication/223245190_Learning_from_Social_Security_Reforms_Two_Different_Cases_Chile_and_ Argentina.

Arza, Camila. 2012a. "The Politics of Counter-reform in the Argentine Pension System: Actors, Political Discourse, and Policy Performance." International Journal of Social Welfare 21: S46-S60. https:// onlinelibrary.wiley.com/doi/full/10.1111/j.1468-2397.2012.00872.x.

---. 2012b. "Who Gets What? Distributive Principles and Impacts of the Argentine Pension System." The Perspective of the World Review 4 (2): 173-196. www.ipea.gov.br/agencia/images/stories/PDFs/ rtm/140221_rtmv4_n2_ingles_cap8.pdf.

Baker, Dean, and Mark Weisbrot. 2002. The Role of Social Security Privatization in Argentina's Economic Crisis. Washington, DC: Center for Economic and Policy Research. http://cepr.net/documents/publications/ argentina_2002_04.htm.

Ball, Robert M. 2010. The Greenspan Commission: What Really Happened. New York: The Century Foundation Press.

Barrionuevo, Alexei. 2008. “Argentina Nationalizes \$30 Billion in Private Pensions." The New York Times, October 21, 2018. www.nytimes.com/2008/10/22/business/worldbusiness/22argentina.html.

Bertranou, Fabio, Esteban Calvo, and Evelina Bertranou. 2009. Is Latin America Retreating from Individual Retirement Accounts? Brief No. 9-14. Chestnut Hill, MA: Center for Retirement Research at Boston College. http://crr.bc.edu/briefs/is-latin-america-retreating-from-individual-retirement-accounts/.

Bethell, Thomas N. 2005. "Roosevelt Redux: Part Two; Robert M. Ball and the Battle for Social Security." The American Scholar, June 1, 2005. https://theamericanscholar.org/roosevelt-redux-part-two/.

Borzutzky, Silvia. 2005. "From Chicago to Santiago: Neoliberalism and Social Security Privatization in Chile." Governance 18: 655-674. https://onlinelibrary.wiley.com/doi/abs/10.1111/j.14680491.2005.00296.x.

Calvert, Peter. 1996. "Privatisation in Argentina." Bulletin of Latin American Research 15 (2): 145-156. https:// www.jstor.org/stable/3339503.

Campbell, Andrea Louise. 2003. How Policies Make Citizens: Senior Political Activism and the American Welfare State. Princeton, NJ: Princeton University Press.

Cortés, R., and A. Marshall. 1999. "Estrategia económica, instituciones y negociación política en la reforma social de los noventa" [Economic Strategy, Institutions and Political Bargaining in the Social Reform of the Nineties]. Desarrollo Económico 39 (154): 195-212.

Dahse, Fernando. 1979. El Mapa de la extrema riqueza: Los Grupos económicos y el proceso de concentración de capitales [The Map of Extreme Wealth: The Economic Groups and the Process of Capital Accumulation]. Santiago, Chile: Editorial Aconcagua.

Diamond, Peter. 1993. “Privatization of Social Security: Lessons from Chile.” NBER Working Paper No. 4510. Cambridge, MA: National Bureau of Economic Research. https://www.nber.org/papers/w4510.

Diamond, Peter, and Salvador Valdes-Prieto. 1994. "Social Security Reforms." In The Chilean Economy: Policy Lessons and Challenges, edited by Barry P. Bosworth, Rudiger Dornbusch, and Ralil Laban, 257-357. Washington, DC: Brookings Institution.

Fultz, Elaine. 2017. "International Experience with Individual Accounts: An Update." Presentation at National Academy of Social Insurance conference, January 26, 2017. https://www.nasi.org/sites/default/ files/events/210/Fultz_2017_NASI_1.pdf.

Galston, William A. 2007. Why President Bush's 2005 Social Security Initiative Failed, and What it Means for the Future of the Program. Washington, DC: Brookings Institution and the Legislating For the Future Project. https://www.brookings.edu/wp-content/uploads/ 2016/06/20070921.pdf. 


\section{Privatization of Social Security Retirement Systems}

Gould, Elise. 2013. Social Security is the Most Effective Anti-Poverty Program in the U.S., In One Chart. Economic Policy Institute, July 30, 2013. https://www.epi.org/blog/social-security-effective-anti-povertyprogram/.

Gregory, Janice M., Thomas N. Bethell, Virginia P. Reno, and Benjamin W. Veghte. 2010. Strengthening Social Security for the Long Run. Social Security Brief No. 35. Washington, DC: National Academy of Social Insurance. https://www.nasi.org/research/2010/strengthening-social-security-long-run.

Hacker, Jacob S. 2005. "Policy Drift: The Hidden Politics of U.S. Welfare State Retrenchment." In Beyond Continuity: Institutional Change in Advanced Political Economies, edited by W. Streeck and K. A. Thelen, 40-82. New York: Oxford University Press.

Hiltzik, Michael. 2005. The Plot Against Social Security: How the Bush Plan is Endangering Our Financial Future. New York: HarperCollins Publishers.

---. 2016. “Chile's Privatized Social Security System, Beloved by U.S. Conservatives, is Falling Apart." Los Angeles Times, August 12, 2016. http://www.latimes. com/business/hiltzik/la-fi-hiltzik-chile-social-security20160812-snap-story.html\#.

Isuani, E.A., R. Rofman, and J. A. San Martino. 1996. "Las Jubilaciones del Siglo XXI: Podemos Gastar a Cuenta?” Boletín Informativo Tecnico 286: 79-104.

Janda, Kenneth. 2006. "Pluralism and Democracy. U.S. Department of State's Bureau of International Information Programs." eJournal USA, June 2006. http://janda.org/bio/american/ ejournalusa.htm.

Kay, Stephen. J. 1999. "Unexpected Privatizations: Politics and Social Security Reform in the Southern Cone." Comparative Politics 31 (4): 403-422. https://www.jstor.org/stable/422237.

Kritzer, Barbara E. 1981. "Social Security Abroad: Chile Changes Social Security." Social Security Bulletin 44 (5): 33-37. https://www.ssa.gov/policy/docs/ssb/v44n5/v44n5p33.pdf.

Kritzer, Barbara E. 1996. "Privatizing Social Security: The Chilean Experience." Social Security Bulletin 59 (3): 45-55. https://www.ssa.gov/policy/docs/ssb/v59n3/v59n3p45.pdf

---. 2002. “Argentina's Pension System." Social Security Bulletin 64 (1): 115-117. https://www.ssa.gov/policy/ docs/ssb/v64n1/v64n1p115.pdf.

---. 2008. “Chile’s Next Generation Pension Reform.” Social Security Bulletin, 68 (2): 69-84. https://www.ssa. gov/policy/docs/ssb/v68n2/v68n2p69.html.

Mesa-Lago, Carmelo. 1994. Changing Social Security in Latin America: Toward Alleviating the Social Costs of Economic Reform. Boulder, CO: Lynne Reinner Publishers, Inc.

---. 2009. "Re-reform of Latin American Private Pensions Systems: Argentinian and Chilean Models and Lessons." The Geneva Papers on Risk and Insurance - Issues and Practice 34 (4): 602-617. https://link. springer.com/article/ 10.1057/gpp.2009.23.

National Commission on Social Security Reform. 1983. “Chapter 2: Findings and Recommendations.” In The 1983 Greenspan Commission on Social Security Reform. https://www.ssa.gov/history/reports/ gspan5.html.

Organisation for Economic Cooperation and Development (OECD). 2017. Pensions at a Glance 2017: OECD and G20 Indicators. Paris, France: OECD Publishing. http://dx.doi.org/10.1787/pension_glance-2017-en.

Piñera, José. N.d. “Empowering Workers in Chile.” José Piñera. http://josepinera.org/ josepinera/Jp_ABC_ Revolucion_pensiones_en.htm.

Reno, Virginia P., Thomas N. Bethell, and Elisa A. Walker. 2011. Social Security Beneficiaries Face 19\% Cut; New Revenue Can Restore Balance. Social Security Brief No. 37. Washington, DC: National Academy of Social Insurance. https://www.nasi.org/research/2011/social-security-beneficiaries-face-19-cutnew-revenue-can-re.

Rix, Sara E. 1995. Chile's Experience with the Privatization of Social Security. Issue Brief No. 23. Washington, DC: AARP Public Policy Institute. http://assets.aarp.org/rgcenter/econ/ib23_chile.pdf. 


\section{Featured Articles}

Romero, Simon, and Raphael Minder. 2012. "Argentina to Seize Control of Oil Company." The New York Times, April 16, 2012. www.nytimes.com/2012/04/17/ business/global/argentine-president-tonationalize-oil-company.html.

Siavelis, Peter M. 2016. “Crisis of Representation in Chile? The Institutional Connection.” Journal of Politics in Latin America 8 (3): 61-93. https://journals.sub.uni-hamburg.de/giga/jpla/article/ download/1004/1011.

Social Security Administration (SSA). 2018. "Benefits Paid by Type of Beneficiary: January 2018." Benefits Paid by Type of Beneficiary. Woodlawn, MD: SSA. https://www.ssa.gov/OACT/ProgData/icp.html.

Turner, John. 2005. Social Security Privatization in Latin America. Washington, DC: AARP Public Policy Institute. https://assets.aarp.org/rgcenter/econ/fs107_latin_ss.pdf.

Weyland, Kurt. 2008. "Bounded Rationality in Latin-American Pension Reform." In Lessons from Pension Reform in the Americas, edited by Stephen J. Kay and Tapen Sinha, 185-211. New York: Oxford University Press. http://pensionresearchcouncil.wharton. upenn.edu/wp-content/ uploads/2015/09/0-19-922680-6-07.pdf.

ELISA WALKER is second-year Master of Public Policy candidate focusing on social policy. She also works in the Social Security Subcommittee of the House Ways and Means Committee, covering retirement policy. She previously worked at the Social Security Administration (SSA), where she led an interagency project piloting early interventions for people who develop potentially disabling conditions, and at the National Academy of Social Insurance, where she analyzed Social Security financing and policy options. She has co-authored numerous publications on Social Security, including Americans Make Hard Choices on Social Security: A Survey with Trade-Off Analysis. Elisa received the Frances Perkins Center's 2015 Open Door Award, given annually to an emerging leader in social justice and economic security, and a 2016 SSA Commissioner's Team Award. She holds a BA in sociology and Spanish from the University of Mary Washington.

\section{ACKNOWLEDGEMENTS}

The author would like to thank Professor Elizabeth Rigby, Associate Editor Miranda Hines, and Managing Editor Claire Oto for their helpful comments and suggestions throughout the editing process. She would also like to thank Professor Mita Marra, for whose class an earlier version of this paper was written. 